\title{
Pengaruh Intellectual Capital Dan Leverage Terhadap Financial Performance Dengan Moderasi Firm Size
}

\author{
Viriany $^{1}$ dan Henny Wirianata ${ }^{2}$ \\ ${ }^{1,2}$ Fakultas Ekonomi dan Bisnis, Universitas Tarumanagara \\ Email Address: \\ viriany@fe.untar.ac.id
}

\begin{abstract}
The purpose of this study is to obtain empirical evidence in regard to the effect of intellectual capital, leverage, and liquidity on financial performance, with firm size as a moderating variable on companies in manufacturing sector, listed in Indonesia Stock Exchange for the 2017-2019 period. The research data was tested by utilizing Eviews version 11. The research samples that used are 64 companies in manufacturing sector with a total of 192 data sorted by utilizing purposive sampling technique. The research results indicate that intellectual capital possess a positive and significant effect on financial performance, while leverage possess insignificant effect on financial performance. Furthermore, the results also indicate that firm size moderate the effect of intellectual capital and leverage on financial performance.
\end{abstract}

Keywords: financial performance, intellectual capital, leverage, firm size.

\begin{abstract}
Abstrak: Tujuan penelitian ini ialah untuk mendapatkan bukti empiris terkait pengaruh intellectual capital dan leverage terhadap financial performance dengan firm size sebagai variabel moderasi pada perusahaan manufaktur yang terdaftar di Bursa Efek Indonesia pada tahun 2017-2019. Data penelitian ini diuji dengan menggunakan software Eviews versi 11. Sampel penelitian ini ialah sejumlah 64 perusahaan manufaktur dengan jumlah total 192 data yang diseleksi dengan menggunakan teknik purposive sampling. Hasil penelitian mengindikasikan bahwa intellectual capital memengaruhi secara positif dan signifikan terhadap financial performance, sedangkan leverage tidak memengaruhi secara signifikan terhadap financial performance. Selain itu, hasil penelitian juga mengindikasikan bahwa firm size memoderasi pengaruh intellectual capital dan leverage terhadap financial performance.
\end{abstract}

Kata Kunci: kinerja keuangan, modal intelektual, tingkat utang, ukuran perusahaan.

\section{PENDAHULUAN}

Perusahaan unggul memiliki keunggulan kompetitif yang memampukan bisnisnya bertahan dan bersaing dalam berbagai masa. Terutama dalam kondisi yang dapat mengancam jalannya proses bisnis, salah satu contoh nyatanya ialah pandemi yang saat ini terjadi. Keunggulan kompetitif harus digunakan agar proses bisnis perusahaan dapat tetap berjalan secara efektif dan efisien. Kepemilikan dan keberhasilan pengelolaan keunggulan 
kompetitif perusahaan dapat ditunjukkan melalui kinerja yang dihasilkan, terutama pada kinerja keuangan. Kinerja keuangan sangat penting untuk menarik perhatian peneliti, ahli keuangan, dan manajemen dari perusahaan lain, sebab menentukan sebuah perusahaan yang sukses merupakan tugas yang sulit, oleh karena itu mereka harus memperhatikan kinerja keuangan yang berkaitan dengan profitabilitas perusahaan (Batool dan Sahi, 2019).

(Wati et al., 2019) mendefinisikan kinerja keuangan sebagai masa depan atau prospek, potensi perkembangan, dan pertumbuhan yang bermanfaat bagi perusahaan. Sedangkan menurut (Daher dan Le Saout, 2015), kinerja keuangan adalah proses pengukuran hasil atas setiap strategi, kebijakan, dan operasional perusahaan dalam ukuran keuangan. Baiknya kinerja keuangan suatu perusahaan menunjukkan kemampuan perusahaan yang baik pula dalam menjalankan operasional usahanya, juga dalam menerapkan strategi dan kebijakan dalam rangka mencapai tujuan utamanya, yaitu laba. Kemampuan perusahaan yang baik tersebut menjadi salah satu faktor utama yang mendukung prospek, potensi, dan masa depan yang baik bagi perusahaan.

Beberapa penelitian terdahulu menunjukkan bahwa kinerja keuangan atau financial performance dapat dipengaruhi oleh berbagai faktor. Namun, faktor-faktor yang menjadi fokus bagi penelitian ini adalah intellectual capital dan leverage. Penelitian ini juga memakai variabel firm size sebagai variabel moderasi.

\section{KAJIAN TEORI}

Stakeholder Theory. (Freeman dan Reed, 1983) menjelaskan bahwa stakeholder ialah individu atau kelompok yang diidentifikasi dapat memengaruhi pencapaian tujuan sebuah organisasi, atau yang dipengaruhi oleh pencapaian tujuan organisasi tersebut. Teori tersebut menekankan pertimbangan atas posisi stakeholders yang dilihat sebagai posisi yang powerfull. Bagi perusahaan dalam mengungkapkan atau tidak mengungkapkan suatu informasi di dalam laporan keuangan ditentukan dengan para stakeholder sebagai pertimbangan utama (Purwaningrat dan Oktarini, 2020).

Resource Based Theory. Dalam artikel dengan judul "A Resource-based view of the firm", (Wernerfelt, 1984) pertama kali menyampaikan sebuah teori yang disebut resource based theory. Teori ini menerangkan bahwa perusahaan mempunyai sumber daya yang dapat menjadikan perusahaan mempunyai kemampuan dalam mengarahkan dirinya untuk mempunyai kinerja jangka panjang yang baik dan memiliki keunggulan bersaing. Mengarahkan resources yang langka dan berharga sehingga membentuk suatu keunggulan bersaing, yaitu mempunyai resources yang dapat bertahan lama dan sulit ditiru, digantikan atau ditransfer (Ulum, 2017).

Pecking Order Theory. (Myers dan Majluf, 1984) dalam artikelnya yang membahas tentang pendanaan perusahaan dan keputusan investasi ketika perusahaan memiliki informasi yang tidak dimiliki oleh investor, memulai argumennya dengan menjelaskan adanya kondisi ketimpangan informasi antara manajemen dengan pihak di luar perusahaan, yaitu manajemen dianggap lebih memahami perusahaan terutama mengenai sumber daya dan prospek yang dimiliki. Kemudian berdasarkan kondisi tersebut mereka mencetuskan sebuah teori yang menyatakan urutan pendanaan yang akan dipilih oleh perusahaan dalam rangka pembiayaan pengembangan usahanya, berdasarkan pertimbangan risiko dan biaya yang ada 
dalam tiap pilihan pendanaan. Teori ini menerangkan bahwa perusahaan mengutamakan penggunaan dana internal dalam mendanai pengembangan usahanya. Urutan sumber pembiayaan yang dijabarkan dalam pecking order theory ialah pertama adalah pendanaan internal yang bersumber dari laba ditahan, kemudian pemakaian utang berupa penerbitan obligasi, dan terakhir melalui alternatif menerbitkan saham (Cristy dan Dewi, 2019).

Financial Performance. Kinerja keuangan (financial performance) adalah proses pengukuran hasil atas setiap strategi, kebijakan, dan operasional perusahaan dalam ukuran keuangan (Daher dan Le Saout, 2015). (Batool dan Sahi, 2019) menyatakan bahwa kinerja keuangan perusahaan manapun berkaitan dengan profitabilitas perusahaan tersebut. Menurut (Bayaraa, 2017), lebih dari ukuran akuntansi lainnya, laba menggambarkan seberapa baik manajemen dalam mengambil kebijakan investasi dan pendanaan. Rasio profitabilitas menimbang efektivitas pengelolaan perusahaan dalam menciptakan laba menggunakan sumber daya kepunyaan perusahaan. Dari beberapa penjelasan tersebut dapat didefinikan bahwa kinerja keuangan merupakan ukuran seberapa baik strategi, kebijakan, dan operasional perusahaan yang dapat dilihat melalui profitabilitas perusahaan tersebut, yaitu kemampuan perusahaan untuk menciptakan laba dengan sumber daya yang ada.

Intellectual Capital. (Kurfi et al., 2017) menjelaskan bahwa intellectual capital adalah sumber daya ilmu pengetahuan yang digunakan oleh organisasi dalam mencapai tujuannya. Modal intelektual (intellectual capital) dapat dilihat sebagai suatu ilmu pengetahuan, dalam pembentukan, suatu kekayaan bersifat intelektual serta pengalaman yang dapat dimanfaatkan oleh perusahaan untuk membentuk kekayaan (Prima, 2018). Dalam rangka mengukur intellectual capital, digunakan model Value Added Intellectual Coefficient (VAIC) yang dinyatakan oleh Pulic di tahun 1997, dirancang untuk menyajikan informasi tentang value creation efficiency atas aset berwujud (tangible asset) dan aset tak berwujud (intangible assets) kepunyaan perusahaan (Ulum, 2017). Semakin besar sumber daya intelektual perusahaan, maka semakin efisien dan efektif pengelolaan operasional perusahaan.

Leverage. Menurut (Abubakar, 2016), financial leverage adalah seberapa besar tingkat penggunaan dana dari hutang di dalam struktur modal perusahaan. Leverage adalah sumber pendanaan perusahaan yang dimanfaatkan oleh perusahaan untuk mendanai asetnya diluar sumber pendanaan lainya seperti modal atau ekuitas (Rachman et al., 2015). Menurut (Utami dan Pardanawati, 2016) rasio leverage adalah rasio yang menyatakan kompetensi perusahaan untuk memenuhi kewajiban jangka pendek dan jangka panjang. Berdasarkan beberapa penjelasan tersebut, dapat disimpulkan bahwa leverage ialah ukuran berupa rasio yang menunjukkan tingkat penggunaan hutang sebagai salah satu alternatif pendanaan perusahaan. Jika dibandingkan dengan pendanaan internal, hutang memiliki risiko dan biaya yang lebih besar sehingga dapat menekan kinerja perusahan.

Firm Size. Menurut (Jekwam dan Hermuningsih, 2018) ukuran perusahaan (firm size) ialah besar kecilnya ukuran suatu perusahaan yang ditentukan dengan menggunakan skala. Perusahaan yang besar mempunyai sumber daya yang besar juga. Ukuran perusahaan adalah suatu skala atau nilai dimana berdasarkan total aktiva, perusahaan dapat digolongkan ukuran besar kecilnya (Rambe, 2020). Jika semakin besar total aktiva maka semakin besar juga 
ukuran perusahaan tersebut. Total aktiva dapat digunakan untuk menilai ukuran perusahaan karena dapat merepresentasikan seberapa besar ukuran perusahaan tersebut, misal semakin besar aktiva, maka akan semakin banyak modal yang ditanam. Berdasarkan beberapa penjelasan tersebut, maka dapat diketahui bahwa ukuran perusahaan ialah suatu skala yang dapat digunakan untuk menentukan besar kecilnya suatu perusahaan, dan salah satu pengukur tersebut ialah total aset.

Kerangka penelitian atas penelitian ini digambarkan sebagai berikut:
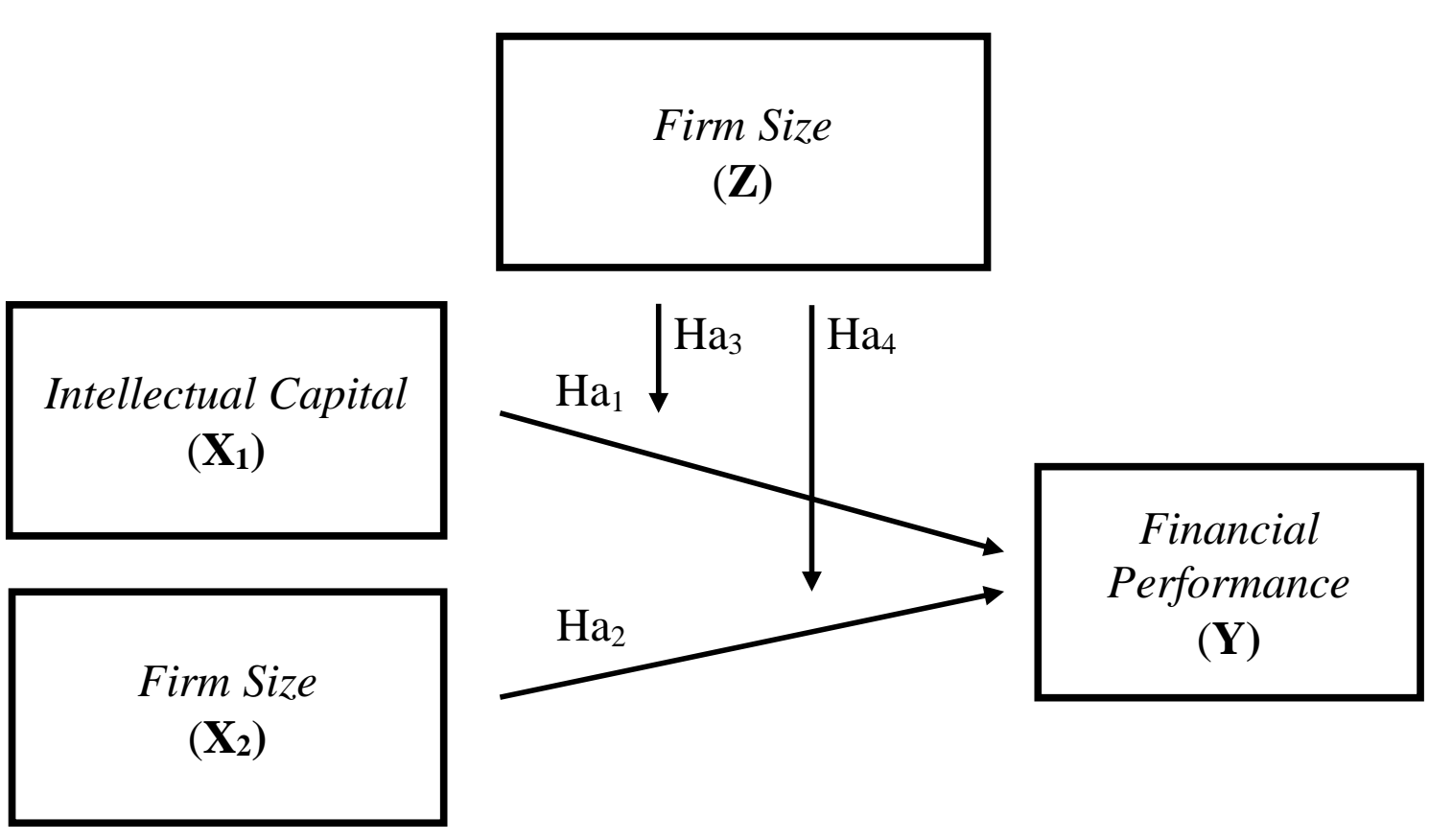

Gambar 1. Model Penelitian

Hipotesis atas model yang dibangun diatas ialah sebagai berikut:

$\mathrm{Ha}_{1}$ : Intellectual capital memengaruhi secara positif dan signifikan terhadap financial performance.

$\mathrm{Ha}_{2}$ : Leverage memengaruhi secara negatif dan signifikan terhadap financial performance.

$\mathrm{Ha}_{3}$ : Firm size memoderasi pengaruh intellectual capital terhadap financial performance.

$\mathrm{Ha}_{4}$ : Firm size memoderasi pengaruh leverage terhadap financial performance.

\section{METODELOGI}

Penelitian ini berusaha mencari tahu efek variabel moderasi pada suatu hubungan di antara variabel bebas dan variabel terikat. Obyek penelitian ini adalah financial performance sebagai variabel terikat, intellectual capital dan leverage sebagai variabel bebas, serta firm size sebagai variabel moderasi. Populasi merujuk pada subyek penelitian, yang mana dalam penelitian ini, populasi yang dipakai ialah perusahaan dalam sektor manufaktur yang terdaftar di Bursa Efek Indonesia pada tahun 2017-2019. Penelitian ini memakai data 
sekunder, yaitu berupa laporan keuangan tahunan perusahaan yang dihimpun dari www.idx.co.id, yang adalah situs resmi Bursa Efek Indonesia.

Penelitian ini memakai teknik purposive sampling, yaitu mengambil sampel penelitian yang disesuaikan dengan kriteria yang telah ditetapkan. Sejumlah kriteria yang digunakan untuk menentukan sampel dalam penelitian ini ialah sebagai berikut: (1) Perusahaan di dalam sektor manufaktur yang secara konsisten terdaftar di Bursa Efek Indonesia (BEI) pada tahun 2017-2019, (2) Perusahaan di dalam sektor manufaktur yang mengalami laba berturutturut pada tahun 2017-2019, (3) Perusahaan di dalam sektor manufaktur yang laporan keuangannya disajikan dalam bentuk mata uang Rupiah, (4) Perusahaan di dalam sektor manufaktur yang secara konsisten menerbitkan laporan keuangan lengkap serta telah diaudit per 31 Desember pada tahun 2017-2019, (5) Perusahaan di dalam sektor manufaktur yang tidak melakukan akuisisi pada tahun 2017-2019, (6) Perusahaan di dalam sektor manufaktur yang memiliki ekuitas positif pada tahun 2017-2019. Berdasarkan sejumlah kriteria tersebut, jumlah perusahaan yang ditetapkan menjadi sampel penelitian ini adalah 64 perusahaan, sepanjang 3 tahun periode penelitian, sehingga diperoleh 192 total sampel dalam penelitian ini.

Financial performance di dalam penelitian ini dinilai dengan rasio return on assets

$$
R O A=\frac{\text { Net Income }}{\text { Total Assets }}
$$

(ROA), yakni rasio antara keuntungan bersih setelah pajak dengan jumlah aset. Return on assets (ROA) dapat dikalkulasikan dengan cara di bawah ini (Puspitosari, 2016):

Intellectual capital di dalam penelitian ini diukur dengan value added intellectual coefficient (VAIC). Model value added intellectual coefficient (VAIC), dapat dihitung dalam 5 tahap (Ulum, 2017).

Pertama, dilakukan kalkulasi atas nilai dari value added (VA). Value added ialah indikator yang menilai secara objektif suatu keberhasilan suatu bisnis dan kemampuan perusahaan untuk menghasilkan nilai atau disebut sebagai value creation. Value added dapat dihitung dengan cara sebagai berikut:

$$
V A=\text { Amortization }+ \text { Depreciation }+ \text { Employee Cost }+ \text { Operating Profit }
$$

Tahap kedua dilakukan dengan mengalkulasi nilai dari capital employed efficiency (CEE). Capital employed efficiency merupakan indikator yang digunakan untuk menunjukkan value added yang dihasilkan oleh satu unit modal fisik. Capital employed efficiency dapat dikalkulasikan dengan cara sebagai berikut:

$$
C E E=\frac{V A}{C E}
$$

Tahap ketiga dilakukan dengan menghitung nilai dari human capital efficiency (HCE). Human capital efficiency merupakan indikator yang dipakai untuk menunjukkan banyaknya Value Added yang dihasilkan dari dana yang dimanfaatkan untuk tenaga kerja. Human capital efficiency dapat dikalkulasikan dengan cara sebagai berikut: 


$$
H C E=\frac{V A}{H C}
$$

Tahap keempat dilakukan dengan menghitung nilai dari structural capital efficiency $(S C E)$. Structural capital efficiency dapat menimbang besar structural capital yang diperlukan untuk menghasilkan satu unit value added. Structural capital efficiency dapat dikalkulasikan dengan cara sebagai berikut:

$$
S C E=\frac{S C}{V A}
$$

Tahap kelima dilakukan dengan menghitung nilai dari value added intellectual coefficient (VAIC). Value added intellectual capital (VAIC) mengalkulasi kemampuan intelektual perusahaan dengan cara memperhitungkan koefisien-koefisien yang telah dikalkulasi sebelumnya. Value added intellectual capital (VAIC) dapat dihitung dengan cara sebagai berikut

$$
V A I C=C E E+H C E+S C E
$$

Leverage dalam penelitian ini dikalkulasi dengan debt to total assets ratio (DAR) yang merupakan skala rasio yang membandingkan total hutang terhadap total aset yang merupakan kepemilikan perusahaan. Debt to total assets ratio (DAR) dapat dikalkulasi dengan cara sebagai berikut (Cristy \& Dewi, 2019):

$$
D A R=\frac{\text { Total Debt }}{\text { Total Asset }}
$$

Firm size dalam penelitian ini dikalkulasi dengan menghitung logaritma natural dari total aset. Formula logaritma natural dari total aset adalah sebagai berikut (Jekwam \& Hermuningsih, 2018):

$$
\text { Size }=\log n(\text { Total Asset })
$$

Penelitian ini menguji data sampel dengan melakukan uji statistik deskriptif, dilanjutkan dengan melakukan uji pemilihan model regresi data panel yang terdiri dari uji hausman, uji chow, dan uji lagrange multiplier. Kemudian dilakukan pengujian hipotesis menggunakan uji statistik F, uji statistik t, dan uji koefisien determinasi. Tingkat signifikansi yang dipakai dalam penelitian ini ialah 0.05 atau sebesar $5 \%$.

\section{HASIL ANALISIS DATA}

Hasil Uji Statistik. Uji statistik deskriptif dapat menjelaskan suatu data dengan menunjukkan nilai varian, maksimum, minimum, rata-rata, standar deviasi, sum, range, kemencengan distribusi, maupun kurtosis. Tujuan dilakukan uji statistik deskriptif ialah untuk menarik kesimpulan atau memberikan gambaran umum mengenai data yang diukur agar lebih mudah dipahami (Ghozali, 2018). Berikut merupakan hasil uji statistik deskriptif dalam penelitian ini: 
Tabel 1. Hasil Pengujian Statistik Deskriptif

\begin{tabular}{|c|c|c|c|c|}
\hline \multicolumn{5}{|c|}{ Date: $05 / 11 / 21 \quad$ Time: $18: 17$} \\
\hline \multicolumn{5}{|c|}{ Sample: 20172019} \\
\hline & $\mathrm{Y}$ & $\mathrm{X} 1$ & $\mathrm{X} 2$ & $\mathrm{Z}$ \\
\hline Mean & 0.084584 & 3.531258 & 0.389114 & 28.64676 \\
\hline Median & 0.055065 & 3.068455 & 0.361525 & 28.52260 \\
\hline Maximum & 0.716020 & 11.81012 & 0.844780 & 32.20096 \\
\hline Minimum & 0.000280 & 1.474730 & 0.066530 & 25.79571 \\
\hline Std. Dev. & 0.096768 & 1.677306 & 0.186868 & 1.430391 \\
\hline Skewness & 3.129633 & 1.853882 & 0.346852 & 0.451633 \\
\hline Kurtosis & 15.92159 & 7.184553 & 2.195988 & 2.686760 \\
\hline Jarque-Bera & 1649.167 & 250.0640 & 9.021281 & 7.312054 \\
\hline Probability & 0.000000 & 0.000000 & 0.010991 & 0.025835 \\
\hline Sum & 16.24005 & 678.0015 & 74.70991 & 5500.178 \\
\hline Sum Sq. Dev. & 1.788542 & 537.3510 & 6.669682 & 390.7892 \\
\hline Observations & 192 & 192 & 192 & 192 \\
\hline
\end{tabular}

Sumber: Hasil output Eviews 11

Dari hasil uji statistik deskriptif pada tabel 1, dapat diketahui bahwa financial performance menunjukkan nilai rata-rata (mean) sejumlah 0.084584 , nilai maksimum sejumlah 0.716020 , nilai minimum sejumlah 0.000280 , dan nilai standar deviasi sejumlah 0.096768. Hasil uji statistik deskriptif juga menunjukkan bahwa intellectual capital menunjukkan nilai mean sejumlah 3.531258, nilai maksimum sejumlah 11.81012 , nilai minimum sejumlah 1.474730, dan nilai standar deviasi sejumlah 1.677306. Sedangkan hasil uji statistik deskriptif atas leverage menunjukkan nilai rata-rata sejumlah 0.389114, nilai maksimum sejumlah 0.844780 , nilai minimum sejumlah 0.066530 , dan nilai standar deviasi sejumlah 0.186868. Selain itu, firm size memiliki nilai rata-rata sejumlah 28.64676, nilai maksimum sejumlah 32.20096, nilai minimum sejumlah 25.79571, dan nilai standar deviasi sejumlah 1.430391.

Selain menggunakan analisis regresi berganda, penelitian ini juga memakai moderated regression analysis (MRA) karena adanya penggunaan variabel moderasi dalam penelitian. Atas dasar tersebut, maka dalam penelitian ini dirumuskan dua persamaan model regresi, yaitu sebelum dan sesudah interaksi dengan variabel moderasi.

Pemilihan Model Estimasi. Sebelum melakukan regresi, harus dilakukan pengujian untuk memilih model regresi data panel yang paling tepat untuk digunakan dalma penelitian ini. Uji chow dilakukan untuk menentukan model yang terbaik antara common effect model dan fixed effect model. 
Tabel 2. Hasil Uji Chow Tanpa Moderasi

\begin{tabular}{|c|c|c|c|}
\hline \multicolumn{4}{|c|}{ Redundant Fixed Effects Tests } \\
\hline \multicolumn{4}{|l|}{ Equation: Untitled } \\
\hline \multicolumn{4}{|c|}{ Test cross-section fixed effects } \\
\hline Effect test & Statistic & d.f. & Prob. \\
\hline Cross-section F & 24.173308 & $(63,126)$ & 0.0000 \\
\hline Cross-section Chi-square & 493.745842 & 63 & 0.0000 \\
\hline
\end{tabular}

Sumber: Hasil output Eviews 11

Hasil uji chow atas persamaan model regresi sebelum adanya variabel moderasi menunjukkan nilai cross section $\mathrm{F}$ sebesar 0.0000 yang lebih kecil nilainya dari 0.05 . Sehingga dapat diketahui bahwa fixed effect model lebih tepat untuk digunakan pada penelitian ini untuk persamaan model regresi sebelum adanya variabel moderasi jika dibandingkan dengan common effect model.

Tabel 3. Hasil Uji Chow dengan Moderasi

\begin{tabular}{|c|c|c|c|}
\hline \multicolumn{4}{|c|}{ Redundant Fixed Effects Tests } \\
\hline \multicolumn{4}{|c|}{ Equation: Untitled } \\
\hline \multicolumn{4}{|c|}{ Test cross-section fixed effects } \\
\hline Effect test & Statistic & d.f. & Prob. \\
\hline Cross-section F & 34.566922 & $(63,123)$ & 0.0000 \\
\hline Cross-section Chi-square & 562.327940 & 63 & 0.0000 \\
\hline
\end{tabular}

Sumber: Hasil output Eviews 11

Hasil uji chow atas persamaan model regresi sesudah adanya variabel moderasi menunjukkan nilai cross section $\mathrm{F}$ sebesar 0.0000 yang lebih kecil nilainya dari 0.05 . Sehingga dapat ditentukan bahwa fixed effect model lebih tepat untuk digunakan pada penelitian ini untuk persamaan model regresi sesudah adanya variabel moderasi jika dibandingkan dengan common effect model.

Setelah pengujian uji chow, berdasarkan hasil uji yang berupa pendekatan fixed effect model atas kedua persamaan model regresi, maka selanjutnya dilakukan uji hausman. Uji hausman dilakukan untuk menentukan model yang paling tepat penggunaanya, antara fixed effect model dan random effect model.

Tabel 4. Hasil Uji Hausman tanpa Moderasi

\begin{tabular}{|c|c|c|c|}
\hline \multicolumn{4}{|c|}{ Correlated Random Effects - Hausman Test } \\
\hline \multicolumn{4}{|l|}{ Equation: Untitled } \\
\hline \multicolumn{4}{|c|}{ Test cross-section random effects } \\
\hline Test Summary & Chi-Sq. Statistic & Chi-Sq. d.f. & Prob. \\
\hline Cross-section random & 8.189711 & 2 & 0.0167 \\
\hline
\end{tabular}

Sumber: Hasil output Eviews 11 
Hasil uji hausman atas persamaan model regresi sebelum adanya variabel moderasi menunjukkan nilai cross section random sebesar 0.0167 yang lebih kecil nilainya dari 0.05 . Sehingga dapat ditentukan bahwa fixed effect model lebih tepat untuk digunakan pada penelitian ini untuk persamaan model regresi sebelum adanya variabel moderasi jika dibandingkan dengan random effect model.

Tabel 5. Hasil Uji Hausman dengan Moderasi

\begin{tabular}{|c|c|c|c|}
\hline \multicolumn{4}{|c|}{ Correlated Random Effects - Hausman Test } \\
\hline \multicolumn{4}{|l|}{ Equation: Untitled } \\
\hline \multicolumn{4}{|c|}{ Test cross-section random effects } \\
\hline Test Summary & Chi-Sq. Statistic & Chi-Sq. d.f. & Prob. \\
\hline Cross-section random & 9.999532 & 5 & 0.0752 \\
\hline
\end{tabular}

Hasil uji hausman atas persamaan model regresi sesudah adanya variabel moderasi menunjukkan nilai cross section random sebesar 0.0752 yang lebih besar nilainya dari 0.05 . Maka dapat ditentukan bahwa random effect model lebih tepat untuk digunakan pada penelitian ini untuk persamaan model regresi sesudah adanya variabel moderasi jika dipadankan dengan fixed effect model.

Dari pengujian untuk menentukan model regresi data panel yang paling tepat untuk dipakai, diketahui bahwa untuk persamaan model regresi tanpa moderasi diperoleh fixed effect model, sedangkan untuk persamaan model regresi sesudah adanya variabel moderasi diperolah random effect model sebagai pendekatan bentuk model regresi data panel yang tepat untuk dipakai pada penelitian ini.

Hasil Uji Regresi. Berdasarkan analisis regresi berganda, maka dapat diketahui persamaan model regresi sebelum adanya interaksi dengan variabel moderasi, yaitu:

$$
\mathbf{Y}=-0.091464+0.057170 \mathbf{X}_{1}-0.066388 \mathbf{X}_{2}+\boldsymbol{e}
$$

Berdasarkan moderated regression analysis, maka dapat diketahui persamaan model regresi sesudah diinteraksikan dengan variabel moderasi ialah sebagai berikut:

$$
\begin{aligned}
& \mathbf{Y}=-1.466527+0.272351 \mathbf{X}_{\mathbf{1}}+1.859413 \mathbf{X}_{\mathbf{2}}+0.050378 \mathbf{Z}-0.007922 \mathbf{X}_{\mathbf{1}} \_\mathbf{Z} \\
& -0.068723 \mathbf{X}_{2} \mathbf{Z}+
\end{aligned}
$$

Berdasarkan persamaan model regresi sebelum adanya variabel moderasi, diketahui konstanta menunjukkan nilai sejumlah -0.091464. Oleh karena itu dapat disimpulkan bahwa apabila intellectual capital $\left(\mathrm{X}_{1}\right)$ dan leverage $\left(\mathrm{X}_{2}\right)$ nilainya ialah 0 , maka financial performance (Y) mempunyai nilai sejumlah -0.091464 satuan. Nilai koefisien intellectual capital $\left(\mathrm{X}_{1}\right)$ sejumlah 0.057170 menunjukkan bahwa apabila variabel lain konstan dan intellectual capital $\left(\mathrm{X}_{1}\right)$ naik satu satuan, maka financial performance $(\mathrm{Y})$ akan mengalami peningkatan sejumlah 0.057170 satuan dan berlaku sebaliknya. Sedangkan nilai koefisien leverage $\left(\mathrm{X}_{2}\right)$ sebesar -0.066388 menunjukkan bahwa apabila variabel lain konstan dan 
leverage $\left(\mathrm{X}_{2}\right)$ naik satu satuan, maka financial performance $(\mathrm{Y})$ akan mengalami penurunan sejumlah 0.066388 satuan dan berlaku sebaliknya.

Dari persamaan model regresi setelah adanya variabel moderasi dan interaksinya dengan variabel independen, diketahui konstanta menunjukkan nilai sejumlah -1.466527 . Oleh karena itu dapat diketahui bahwa apabila intellectual capital $\left(\mathrm{X}_{1}\right)$, leverage $\left(\mathrm{X}_{2}\right)$, firm size (Z), interaksi intellectual capital dan firm size ( $\left.\mathrm{X}_{1} \_\mathrm{Z}\right)$, serta interaksi leverage dan firm size $\left(\mathrm{X}_{2} \mathrm{Z}\right)$ nilainya ialah 0 , maka financial performance $(\mathrm{Y})$ memiliki nilai sebesar 1.466527 satuan. Nilai koefisien intellectual capital $\left(\mathrm{X}_{1}\right)$ sebesar 0.272351 menunjukkan bahwa apabila variabel lain konstan dan intellectual capital $\left(\mathrm{X}_{1}\right)$ naik satu satuan, maka financial performance (Y) akan mengalami peningkatan juga sejumlah 0.272351 satuan dan berlaku sebaliknya. Sedangkan nilai koefisien leverage $\left(\mathrm{X}_{2}\right)$ sebesar 1.859413 menunjukkan bahwa apabila variabel lain konstan dan leverage $\left(\mathrm{X}_{2}\right)$ naik satu satuan, maka financial performance (Y) akan mengalami peningkatan juga sejumlah 1.859413 satuan dan berlaku sebaliknya. Nilai koefisien firm size (Z) sebesar 0.050378 menunjukkan bahwa apabila variabel lain konstan dan firm size $(\mathrm{Z})$ naik satu satuan, maka financial performance $(\mathrm{Y})$ akan mengalami peningkatan juga sejumlah 0.050378 satuan dan berlaku sebaliknya. Berbeda dengan sebelumnya, nilai koefisien interaksi intellectual capital dan firm size $\left(\mathrm{X}_{1 \_Z}\right.$ ) sebesar -0.007922 menunjukkan bahwa apabila variabel lain konstan dan interaksi intellectual capital dan firm size ( $\left.\mathrm{X}_{1} \mathrm{Z}\right)$ naik satu satuan, maka financial performance $(\mathrm{Y})$ akan mengalami penurunan sejumlah 0.007922 satuan dan berlaku sebaliknya. Nilai koefisien interaksi leverage dan firm size $\left(\mathrm{X}_{2}\right.$ Z $)$ sebesar -0.068723 menunjukkan bahwa apabila variabel lain konstan dan interaksi leverage dan firm size $\left(\mathrm{X}_{2} \mathrm{Z}\right)$ naik satu satuan, maka financial performance (Y) akan mengalami penurunan sejumlah 0.068723 satuan dan berlaku sebaliknya.

Uji statistik F dilakukan atas dasar tujuan untuk mengetahui apakah seluruh variabel independen pada penelitian ini secara simultan memengaruhi secara signifikan terhadap variabel dependen. Berdasarkan hasil uji statistik F yang dilakukan pada penelitian ini, dapat dilihat bahwa nilai probabilitas signifikansi adalah 0.000000 , atau dengan kata lain lebih kecil dari tingkat signifikansi $0.05(5 \%)$. Atas dasar tersebut, dapat ditentukan bahwa variabel intellectual capital $\left(\mathrm{X}_{1}\right)$ dan leverage $\left(\mathrm{X}_{2}\right)$ secara simultan memiliki pengaruh signifikan terhadap financial performance $(\mathrm{Y})$.

Uji statistik t dilakukan dengan tujuan untuk menentukan apakah terdapat variabel independen memengaruhi secara signifikan terhadap variabel dependen secara parsial, baik sebelum ataupun sesudah diinteraksikan dengan variabel moderasi. Uji parsial dilakukan dengan tingkat signifikansi senilai 0.05 atau 5\%, variabel independen disimpulkan memengaruhi secara signifikan terhadap variabel dependen jika mempunyai nilai probabilitas uji statistik t lebih kecil dari tingkat signifikansi $0.05(5 \%)$. Hasil uji statistik $\mathrm{t}$ atau uji parsial untuk penelitian ini ditunjukkan dalam tabel berikut ini. 
Tabel 6. Hasil Uji Statistik t tanpa Moderasi

\begin{tabular}{|c|c|c|c|c|}
\hline \multicolumn{5}{|c|}{ Dependent Variable: Y } \\
\hline \multicolumn{5}{|c|}{ Method: Panel Least Squares } \\
\hline \multicolumn{5}{|c|}{ Date: $05 / 11 / 21 \quad$ Time: $18: 34$} \\
\hline \multicolumn{5}{|c|}{ Sample: 20172019} \\
\hline \multicolumn{5}{|c|}{ Periods Included: 3} \\
\hline \multicolumn{5}{|c|}{ Cross-sections included:64 } \\
\hline \multicolumn{5}{|c|}{ Total panel (balanced) observations: 192} \\
\hline Variable & Coefficient & Std. Error & $\mathrm{t}$-Statistic & Prob. \\
\hline $\mathrm{C}$ & -0.091464 & 0.018762 & -4.874852 & 0.0000 \\
\hline $\mathrm{X} 1$ & 0.057170 & 0.002223 & 25.71762 & 0.0000 \\
\hline $\mathrm{X} 2$ & -0.066388 & 0.043214 & -1.536262 & 0.1270 \\
\hline
\end{tabular}

Sumber: Hasil output Eviews 11

Atas dasar hasil pengujian statistik t tanpa adanya variabel moderasi, dapat ditentukan bahwa variabel independen yang pertama, yaitu modal intelektual memengaruhi secara positif dan signifikan terhadap variabel dependen (kinerja keuangan) secara parsial. Hasil uji pada tabel tersebut menunjukkan koefisien positif dan nilai probabilitas sejumlah 0,0000 yang nilainya lebih kecil dari tingkat signifikansi yaitu senilai 0,05 atau $5 \%$.

Variabel independen leverage pada tabel di atas memperlihatkan nilai koefisien yang negatif dan mempunyai nilai probabilitas sejumlah 0,1270 dimana nilai tersebut lebih besar nilainya dari 0,05 . Sehingga dapat ditentukan bahwa secara parsial leverage tidak memengaruhi secara signifikan terhadap kinerja keuangan.

Tabel 7. Hasil Uji Statistik t dengan Moderasi

\begin{tabular}{|c|c|c|c|c|}
\hline \multicolumn{5}{|c|}{ Dependent Variable: Y } \\
\hline \multicolumn{5}{|c|}{ Method: Panel EGLS (Cross-section random effects) } \\
\hline \multicolumn{5}{|c|}{ Date: $05 / 11 / 21 \quad$ Time: $18: 36$} \\
\hline \multicolumn{5}{|c|}{ Sample: 20172019} \\
\hline \multicolumn{5}{|c|}{ Periods Included: 3} \\
\hline \multicolumn{5}{|c|}{ Cross-sections included:64 } \\
\hline \multicolumn{5}{|c|}{ Total panel (balanced) observations: 192} \\
\hline \multicolumn{5}{|c|}{ Swamy and Arora estimator of component variances } \\
\hline Variable & Coefficient & Std. Error & t-Statistic & Prob. \\
\hline $\mathrm{C}$ & -1.466527 & 0.281485 & -5.209973 & 0.0000 \\
\hline $\mathrm{X} 1$ & 0.272351 & 0.030826 & 8.835228 & 0.0000 \\
\hline $\mathrm{X} 2$ & 1.859413 & 0.590814 & 3.147205 & 0.0019 \\
\hline $\mathrm{Z}$ & 0.050378 & 0.010026 & 5.024922 & 0.0000 \\
\hline $\mathrm{X} 1 \_\mathrm{Z}$ & -0.007922 & 0.001128 & -7.025080 & 0.0000 \\
\hline $\mathrm{X} 2 \_\mathrm{Z}$ & -0.068723 & 0.020753 & -3.311490 & 0.0011 \\
\hline
\end{tabular}

Sumber: Hasil output Eviews 11

Sedangkan atas dasar hasil uji statistik t dengan adanya variabel moderasi, dapat ditentukan bahwa variabel independen yang pertama, yaitu modal intelektual yang diinteraksikan 
dengan variabel moderasi ukuran perusahaan memengaruhi secara negatif dan signifikan terhadap variabel dependen (kinerja keuangan) secara parsial. Hasil uji pada tabel tersebut menunjukkan koefisien negatif dan nilai probabilitas sejumlah 0,0000 yang nilainya lebih kecil dari tingkat signifikansi yaitu 0,05 atau $5 \%$.

Variabel independen leverage yang diinteraksikan dengan variabel moderasi ukuran perusahaan dalam tabel di atas memperlihatkan nilai koefisien yang negatif dan mempunyai nilai probabilitas sejumlah 0,0011 dimana nilai tersebut lebih kecil nilainya dari 0,05. Sehingga dapat disimpulkan bahwa leverage dengan adanya moderasi ukuran perusahaan memengaruhi secara negatif dan signifikan terhadap kinerja keuangan.

Pengujian koefisien determinasi (adjusted $R$-squared) dilakukan dengan tujuan untuk mengetahui besaran proporsional atas kemampuan variabel independen pada penelitian ini, intellectual capital $\left(\mathrm{X}_{1}\right)$ dan leverage $\left(\mathrm{X}_{2}\right)$ dalam menjelaskan financial performance $(\mathrm{Y})$ sebagai variabel independen. Hasil pengujian koefisien determinasi pada penelitian ini memperlihatkan nilai sejumlah 0.957318 sebelum adanya interaksi dengan variabel moderasi, dan 0.855141 sesudah adanya interaksi dengan variabel moderasi. Atas dasar hasil tersebut dapat ditentukan bahwa sebelum adanya interaksi dengan variabel moderasi, intellectual capital $\left(\mathrm{X}_{1}\right)$ dan leverage $\left(\mathrm{X}_{2}\right)$ mampu menjelaskan financial performance $(\mathrm{Y})$ sebesar $95.7318 \%$ dan sisanya sebesar $4.2682 \%$ dapat dijelaskan oleh variabel lain di luar variabel yang tercantum dalam penelitian ini. Sedangkan setelah adanya interaksi dengan variabel moderasi, intellectual capital $\left(\mathrm{X}_{1}\right)$, leverage $\left(\mathrm{X}_{2}\right)$, firm size $(\mathrm{Z})$, interaksi intellectual capital dan firm size $\left(\mathrm{X}_{1} \_\mathrm{Z}\right)$, serta interaksi leverage dan firm size $\left(\mathrm{X}_{2} \mathrm{Z}\right)$ memiliki kemampuan sebesar $85.5141 \%$ dalam menjelaskan financial performance (Y), sisanya sebesar $14.4859 \%$ dapat dijelaskan oleh variabel lain di luar variabel yang tercantum pada penelitian ini.

\section{DISKUSI}

Berdasarkan pengujian yang telah dilakukan dalam penelitian ini dapat tentukan bahwa intellectual capital memengaruhi secara positif dan signifikan terhadap financial performance sehingga $\mathrm{Ha}_{1}$ diterima. Kesimpulan tersebut sejalan dengan hasil penelitian (Kurfi et al., 2017), (Hamdan, 2018), (Smriti dan Das, 2018), dan (Puspitosari, 2016). Namun tidak sejalan dengan hasil penelitian (Herawati, 2017) dan (Prima, 2018) yang menyatakan bahwa intellectual capital tidak memengaruhi secara signifikan terhadap financial performance. Hasil penelitian atas variabel intellectual capital ini mengindikasikan bahwa intellectual capital perusahaan dapat meningkatkan perolehan laba perusahaan sehingga meningkatkan kinerja keuangan perusahaan. Sejalan dengan resourcebased theory, kepemilikan perusahaan atas pengetahuan dan keahlian serta aset intelektual lainnya dapat membantu perusahaan menjalankan kegiatan usahanya dengan lebih efisien dan efektif, serta menciptakan laba yang lebih besar serta kinerja keuangan yang lebih baik.

Hasil uji hipotesis kedua menunjukkan bahwa $\mathrm{Ha}_{2}$ ditolak, leverage memengaruhi secara negatif namun tidak signifikan terhadap financial performance. Hasil tersebut berbeda dengan hasil penelitian (Ibhagui dan Olokoyo, 2018), (Evgeny, 2015), serta (Cristy dan Dewi, 2019). Namun hasil penelitian ini sependapat dengan hasil penelitian (Jaleel dan Olayiwola, 2017) serta (Widyastuti, 2019) yang menyatakan bahwa leverage tidak memengaruhi secara signifikan terhadap financial performance. 
Hasil uji hipotesis ketiga memperlihatkan bahwa Ha3 diterima, firm size memoderasi pengaruh intellectual capital terhadap financial performance. Hasil uji tersebut sependapat dengan hasil penelitian (Purwaningrat dan Oktarini, 2020). Koefisien regresi intellectual capital sebelum dimoderasi adalah sebesar 0.057170, namun setelah dimoderasi menjadi 0.007922. Sehingga dapat ditentukan bahwa firm size memperlemah pengaruh intellectual capital terhadap financial performance. Bertambah besarnya ukuran suatu perusahaan, maka semakin bertambah juga banyaknya pihak atau stakeholder yang terlibat atas kegiatan usaha perusahaan tersebut. Sesuai dengan teori stakeholder, perusahaan yang lebih besar dituntut untuk menyampaikan informasi secara lebih terbuka dan dapat lebih menjangkau berbagai pihak yang merupakan pemangku kepentingan. Pengungkapan tersebut ternyata lebih mengungkap besarnya biaya yang ditanggung oleh perusahaan untuk mengelola dan memelihara modal intelektualnya. Sehingga memperjelas bahwa kepemilikan modal intelektual tidak berpengaruh secara positif terhadap kinerja keuangan, dikarenakan besarnya biaya yang sebenarnya harus ditanggung oleh perusahaan atas kepemilikan modal intelektualnya.

Hasil uji hipotesis keempat menunjukkan bahwa $\mathrm{Ha}_{4}$ diterima, firm size memoderasi pengaruh leverage terhadap financial performance. Hasil uji tersebut sejalan dengan hasil penelitian (Vithessonthi dan Tongurai, 2015). Koefisien regresi intellectual capital sebelum dimoderasi adalah sebesar -0.066388 , namun setelah dimoderasi menjadi -0.068723 . Sehingga dapat ditentukan bahwa firm size memperkuat pengaruh leverage terhadap financial performance. Bertambah besarnya ukuran perusahaan, maka bertambah besar juga jumlah aset. Untuk memenuhi kebutuhan pendanaan aset mungkin membutuhkan adanya pendanaan eksternal. Apabila merujuk pada pecking order theory, maka perusahaan akan memilih memanfaatkan pendanaan hutang. Maka dengan dasar tersebut, bertambah besarnya aset, mengakibatkan bertambah besar juga pendanaan yang mungkin berupa hutang yang diperlukan perusahaan. Sehingga akhirnya menambah beban hutang yang ditanggung oleh perusahaan. Akibat beban hutang tersebut, laba yang dihasilkan dan kinerja keuangan perusahaan menjadi tertekan.

\section{KESIMPULAN}

Berdasarkan penelitian yang telah dilaksanakan, terdapat keterbatasan yang ditemukan, di antaranya yaitu periode penelitian yang dipakai hanya dari tahun 2017 hingga 2019, penelitian ini hanya menguji dua variabel independen (intellectual capital dan leverage), satu variabel dependen (financial performance), dan satu variabel moderasi (firm size), serta populasi dalam penelitian ini hanya mencakup sektor manufaktur yang terdaftar dalam Bursa Efek Indonesia (BEI).

Beberapa saran yang dapat diberikan atas keterbatasan-keterbatasan yang telah disebutkan untuk penelitian berikutnya adalah dapat menambahkan periode penelitian sehingga hasil penelitian tesebut dapat menggambarkan keadaan dan situasi atas jangka waktu yang relatif lebih panjang. Selanjutnya juga dapat menambah dan memakai variabel lain diluar variabel yang terdapat di dalam penelitian ini. Masih terdapat berbagai faktor yang dapat memengaruhi kinerja keuangan perusahaan yang menarik untuk diteliti. Serta diharapkan untuk tidak melakukan penelitian sebatas pada perusahaan dengan sektor manufaktur melainkan dapat menggunakan perusahaan-perusahaan dari sektor lain yang terdaftar di Bursa Efek Indonesia (BEI). Agar kemudian dibandingkan serta diketahui 
apakah penelitian pada sektor yang berbeda dapat memperoleh hasil yang berbeda atau sama, serta untuk mendapatkan hasil yang lebih tepat untuk digambarkan secara umum.

\section{DAFTAR PUSTAKA}

Abubakar, A. (2016). Financial leverage and financial performance: Evidence from the Health Care Sector of the Nigerian Stock Exchange from 2005- 2014. ADSU Journal of Economics and Interrelated Disciplines, 1(2), 45-64.

Ajija, S. R., Sari, D. W., Setianto, R. H., dan Primanti, M. R. (2011). Cara cerdas menguasai Eviews. Jakarta: Salemba Empat.

Batool, A., and Sahi, A. (2019). Determinants of Financial Performance of Insurance Companies of USA and UK during Global Financial Crisis (2007-2016). International Journal of Accounting Research, 5(1), 23-33.

Bayaraa, B. (2017). Financial Performance Determinants of Organizations: The Case of Mongolian Companies. Journal of Competitiveness, 9(3), 22-33.

Cristy, M., dan Dewi, S. P. (2019). Faktor-Faktor Yang Mempengaruhi Kinerja Keuangan Pada Perusahaan Manufaktur Periode 2015-2017. Jurnal Multiparadigma Akuntansi Tarumanagara, I(3), 808-816.

Daher, L., and Le Saout, E. (2015). The Determinants of the Financial Performance of Microfinance Institutions: Impact of the Global Financial Crisis. Strategic Change, 24(2), 131-148.

Evgeny, I. (2015). The Impact Of Financial Leverage On Firm Performance: Evidence From Russia. Journal of Corporate Finance Research Koрпоративные Финансы, 9(2).

Freeman, R. E., and Reed, D. L. (1983). Stockholders and Stakeholders: A New Perspective on Corporate Governance. California Management Review, 25(3), 88-106.

Ghozali, I. (2018). Aplikasi analisis multivariete dengan program IBM SPSS 25. Semarang: Badan Penerbit Universitas Diponegoro.

Hamdan, A. (2018). Intellectual capital and firm performance. International Journal of Islamic and Middle Eastern Finance and Management, 11(1), 139-151.

Herawati, H. (2017). Pengaruh Modal Intelektual Terhadap Kinerja Keuangan Perusahaan (Studi Empiris Pada Bursa Efek Indonesia). EKOMBIS REVIEW: Jurnal Ilmiah Ekonomi Dan Bisnis, 5(2), 151-161.

Ibhagui, O. W., and Olokoyo, F. O. (2018). Leverage and firm performance: New evidence on the role of firm size. The North American Journal of Economics and Finance, 45, 57-82.

Jaleel, A., and Olayiwola, B. (2017). Effect of Leverage on Firm Performance in Nigeria: A Case of Listed Chemicals and Paints Firms in Nigeria. Global Journal of Management and Business Research: Accounting and Auditing, 17(2), 14-24.

Jekwam, J. J., dan Hermuningsih, S. (2018). Peran Ukuran Perusahaan (Size) Dalam Memoderasi Corporate Social Responsibility Dan Likuiditas Terhadap Kinerja Keuangan Pada Perusahaan Pertambangan Yang Terdaftar Di BEI. Upajiwa Dewantara, 2(1), 76-85.

Kurfi, S. A., Udin, N. M., and Bahamman, S. M. (2017). The Impact Of Intellectual Capital On The Financial Performance Of Listed Nigerian Food Products Companies. Journal of Accounting and Taxation, 9(11), 147-160.

Myers, S. C., and Majluf, N. S. (1984). Corporate financing and investment decisions when 
firms have information that investors do not have. Journal of Financial Economics, $13(2), 187-221$.

Prima, A. P. (2018). Pengaruh Modal Intelektual Terhadap Kinerja Keuangan Perusahaan Perbankan Pada Bursa Efek Indonesia. Jurnal Akrab Juara, 3(1), 184-203.

Purwaningrat, P. A., dan Oktarini, L. N. (2020). Efektifkah Firm Size Memoderasi Hubungan Antara Intellectual Capital Dengan Kinerja Keuangan Perusahaan. JUIMA (Jurnal Ilmu Manajemen), 10(1), 11-21.

Puspitosari, I. (2016). Pengaruh Modal Intelektual terhadap Kinerja Keuangan pada Sektor Perbankan. EBBANK, 7(1), 43-53.

Rachman, A. N., Rahayu, S. M., dan Topowijono. (2015). Pengaruh Good Corporate Governance Dan Financial Leverage Terhadap Kinerja Keuangan Dan Nilai Perusahaan. Jurnal Administrasi Bisnis, 27(1), 1-10.

Rambe, B. H. (2020). Analisis Ukuran Perusahaan, Free Cash Flow(FCF) Dan Kebijakan Hutang Terhadap Kinerja Keuangan Pada Perusahaan Manufaktur Yang Terdaftar Di Bursa Efek Indonesia. ECOBISMA (Jurnal Ekonomi, Bisnis Dan Manajemen), 7(1), 54-64.

Smriti, N., and Das, N. (2018). The impact of intellectual capital on firm performance: a study of Indian firms listed in COSPI. Journal of Intellectual Capital, 19(5), 935-964.

Ulum, I. (2017). INTELLECTUAL CAPITAL: Model Pengukuran, Framework Pengungkapan\& Kinerja Organisasi. Malang: UMMPress.

Utami, W. B., dan Pardanawati, S. L. (2016). Pengaruh Likuiditas, Solvabilitas, Dan Manajemen Aset Terhadap Kinerja Keuangan Pada Perusahaan Go Publik Yang Terdaftar Dalam Kompas 100 Di Indonesia. Jurnal Akuntansi Dan Pajak, 17(1), 6372.

Vithessonthi, C., and Tongurai, J. (2015). The Effect of Leverage on Performance: Domestically-Oriented vs. Internationally-Oriented Firms. Research in International Business and Finance, 34(May), 265-280.

Wati, P. S., Mulyadi, J., dan Rachbini, W. (2019). Determinan Kinerja Keuangan Dengan Size Sebagai Moderasi. Jurnal Ecodemica: Jurnal Ekonomi, Manajemen, Dan Bisnis, 3(2), 257-268.

Wernerfelt, B. (1984). A resource-based view of the firm. Strategic Management Journal, $5(2), 171-180$.

Widyastuti, M. (2019). Analysis Of Liquidity, Activity, Leverage, Financial Performance And Company Value In Food And Beverage Companies Listed On The Indonesia Stock Exchange. International Journal of Economics and Management Studies, 6(5), $52-58$. 